\title{
Interactions between frugivorous bats (Chiroptera: Phyllostomidae) and Piper tuberculatum (Piperaceae) in a tropical dry forest in Valle del Cauca, Colombia
}

\author{
Sebastián Montoya-Bustamante ${ }^{1}$, Vladimir Rojas-Díaz ${ }^{2}$ \& Alba Marina Torres-González ${ }^{1}$ \\ 1. Universidad del Valle, Apartado Aéreo 25360, Cali, Colombia; sebastian093_2@hotmail.com, \\ alba.torres@correounivalle.edu.co \\ 2. Wildlife Conservation Society Colombia, Calle 2 \#42-23, Cali, Colombia; vrojas@wcs.org
}

Received 31-VII-2015. C Corrected 14-XII-2015. Accepted 29-I-2016.

\begin{abstract}
In any ecosystem, fruits are resources that vary in time and space as well as in nutritional content. Coexistence of species from a trophic guild depends on the division and use of resources. Therefore, the organisms that depend on them as a food source, tend to show a certain degree of specialization. This way, understanding the factors that influence the dynamics of seed dispersal is important for the regeneration and conservation of tropical ecosystems. Our aim was to determine variation in consumption of Piper tuberculatum by fruit bat assemblages in the village of Robles (Jamundí, Valle del Cauca, Colombia). P. tuberculatum is a resource used not only by wildlife but also by people in the village of Robles. Bats were captured in mist nets between June and November 2014, their feces were collected, and the length of the forearm, wing area, leg length and mass were recorded. At the Universidad del Valle seed laboratory, fecal samples were washed, and their content determined. Of the 14 species captured, Sturnira lilium, Carollia brevicauda, Carollia perspicillata and Artibeus lituratus showed signs of having consumed P. tuberculatum. Sturnira lilium was the main consumer of $P$. tuberculatum fruits, with the greatest number of consumption events of fruit from this plant species, whereas the other bats showed more diversified consumption events. The greatest niche overlap was recorded between C. brevicauda and $C$. perspicillata, species that showed similar sizes (i.e., wing area and forearm length) followed by S. lilium and $C$. perspicillata. In contrast, A. lituratus showed the least niche overlap with the other three fruit bats captured. In conclusion, Sturnira lilium showed an interaction Sturnira-Piper, which is the result of low Solanum availability, and this bat species was the largest consumer of $P$. tuberculatum in the region. Rev. Biol. Trop. 64 (2): 701-713. Epub 2016 June 01.
\end{abstract}

Key words: diet, seed dispersal, fruit bats, pipilongo, Sturnira, Carollia.

How coexisting animal populations divide resources is a key determinant of species richness in a particular area (Pianka, 1974). Resource use is not random; in fact, patterns of use in time and space have been described (Heithaus, Fleming, \& Opler, 1975; Fleming, 1981; Fleming, 1985; Fleming, 1991). Such resources, including food and shelter, are generally limited, leading to changes in population growth, habitat selection and food consumption (Feldhamer, Drickamer, \& Vessey, 2003).

Organisms adapted to use certain resources are more likely to survive and reproduce.
Conversely, organisms that coexist with the aforementioned organisms and depend on the same resources but are not adapted for their use are often excluded from the area and may even become locally extinct as a consequence, among other reasons, of inter-specific competition (Hill \& Smith, 1984; Feldhamer et al., 2003). The historical effects of competition are generally observed as significant differences in morphology, individual behavior or foraging and diet of the species (Fleming, 1979).

Plants of the genus Piper (Piperaceae) are a very common food resource in neotropical 
forests. This genus contains more than 2000 species distributed in the tropical regions of both hemispheres and often is of great commercial, economic and medicinal importance (Parmar et al., 1997; Quijano-Abril, CallejasPosada, \& Miranda-Esquivel, 2006). These plants are erect herbs or climbers, shrubs or small understory trees, well known as pioneer plants that colonize roads, gaps and forest edges and are involved in the processes of regeneration and maintenance of plant diversity (Fleming 1985; Parmar et al., 1997; Thies \& Kalko, 2004). Piper (Piperaceae) has been considered a key mutualist species for fruit bats (Fleming, 1985; Thies \& Kalko, 2004).

Neotropical fruit bats belong to the Phyllostomidae family. This is one of the most diverse bat families with respect to foraging strategies and eating habits, which vary from the consumption of fruits to pollen to animals, and even blood (Smith, 1976; Gardner, 2007a). Phyllostomidae is the most diverse family of neotropical bats, consisting of 44 genera and more than 140 species among its South American representatives (Feldhamer et al., 2003; Gardner, 2007a). Sixteen of those genera are frugivorous, among which, Carollia and Sturnira stand out due to their wide geographic distribution, great local abundance, and important roles they play during successional stages in neotropical forests (Gardner, 2007b; Gardner, 2007c; McLellan \& Koopman, 2007; Muscarella \& Fleming 2007).

Bats from the genus Carollia are known to have a mutualist association with plants of the genus Piper. These bats are considered specialists and are the main dispersers of this plant genus (Marinho-Filho, 1991; Fleming \& Kress, 2011). Several studies have assessed the influence of different factors on the use and dispersal of Piper by Carollia. Those factors include the intrinsic characteristics of the fruits, such as smell, shape and hardness (Thies, Kalko, \& Schnitzler, 1998; Dumont, 1999), as well as characteristics of the bats, such as body size, behavior, circadian cycle, reproduction and food handling behavior (Fleming 1991; Bonaccorso et al., 2006; Mello, Schittini,
Selig, \& Bergallo, 2004). However, those studies initially compared Piper use only among Carollia spp., eventually including other species that consume these fruits and could coexist, such as bats from the genus Sturnira (Saldaña-Vázquez, Sosa, Iñiguez-Dávalos, \& Schondube, 2013). Although it includes a great variety of fruits, the diet of Sturnira is generally dominated by fruits of the genus Solanum (Marinho-Filho, 1991; Mello, Kalko, \& Silva, 2008; Saldaña-Vázquez et al., 2013).

Plant-bat interactions between CarolliaPiper and Sturnira-Solanum (with Piper species in second place) have been documented particularly in Central America, in tropical premontane wet areas, cloud forests and lowland tropical dry areas (Fleming, Heithaus, \& Sawyer, 1977; Heithaus et al., 1975; Fleming 1981; Fleming 1986; Fleming 1991; López \& Vaughan 2007; Saldaña-Vásquez et al., 2013). These interactions have been so commonly found that it has been suggested as a mechanism of resource partitioning between these organisms, allowing their coexistence by reducing the level of potential competition (Fleming, 1979; Marinho-Filho, 1991).

In plant-animal seed dispersal associations, plants provide nutritional tissue that is associated with the seeds. Animals eat those fruits and later regurgitate, defecate or drop the viable seeds at varying distances (CharlesDominique, 1993). Due to species richness, high biomass, feeding habits and mobility, fruit-eating chiropterans play important roles as seed dispersers in tropical ecosystems and in the genetic flow within and between plant populations (Dumont, 2003; Voigt, Kelm, Bradley, \& Ortmann, 2009).

Piper tuberculatum Jacq, known as "pipilongo," is a plant of ethnobotanical importance to the people in the village of Robles in Cauca valley, who have been using it for more than 200 years for culinary and medicinal purposes. This species is abundant in the area and is subject to an early stage of agricultural management (C. González, personal communication, February 14, 2014). Therefore, the study of the factors that affect the reproductive biology of 
P. tuberculatum is relevant for the conservation of the natural plant associations among which these people live. The goal of the present study was to evaluate the variation in consumption of $P$. tuberculatum by fruit bats present in the area. Four predictions were proposed: 1) Carollia has preferences for plants of the genus Piper, 2) Piper and other plants are eaten in similar proportions by other frugivores, 3) similarities in bat morphology are reflected in their diet preferences, and 4) Carollia populations are philopatric, in accordance with pipilongo availability.

\section{MATERIALS AND METHODS}

Study area: Sampling was conducted in several locations in the village of Robles, city of Jamundí, department of Valle del Cauca, Colombia ( $\left.3^{\circ} 07^{\prime} 42^{\prime \prime} \mathrm{N}-76^{\circ} 35^{\prime} 34^{\prime \prime} \mathrm{W}\right)$. This area is located at an average altitude of 990 $\mathrm{m}$ and corresponds to the Tropical Dry Forest life zone (T-Df) according to Holdridge (1967). The weather shows a bimodal pattern with two rainy seasons per year (April-May and October-November) interspersed with two dry periods (Chacón, Osorio-García, Achury, \& Bermúdez, 2012).

In Robles, four sites were sampled during the six-month study: two sites were away from the village (the traditional farms from La Isla district and the farm "La Daniela" in the El Guavito district), and two sites were close to town (the crop areas of the agricultural educational Institute Horacio Gómez Gallo - Main Campus, and the swine farm production " $\mathrm{La}$ Manga"). The traditional farms from La Isla district consist of areas of agricultural production of mango, avocado, sapote, lemon, mandarin orange, orange, cocoa, guava and banana. $P$. tuberculatum could be found associated with hedges. At "La Daniela" farm, areas adjacent to the Robles stream were sampled within a secondary tropical dry forest. The vegetation cover from the crop areas of the agricultural educational Institute Horacio Gómez Gallo - Main Campus is similar to that of the traditional farms. However, here, the crops, unlike on the farms, show spatial structure. Finally, the swine farm "La Manga" borders the stock pastures and houses of Robles residents, yet in this site, there are mango and guava trees and more than 30 individual $P$. tuberculatum plants.

Management of $P$. tuberculatum by farmers results in an aggregated distribution of this plant species. Most individuals are found in the backyards of the village residents and associated with hedges, whereas they are not allowed to grow in crop areas (C. González, personal communication, February 14, 2014).

Bat capture: Six mist nets were used to capture bats, three were $12 \times 3 \mathrm{~m}$ and three were $6 \times 3 \mathrm{~m}$, and all were open between 19:0000:00 hours for 19 nights per month from June to November 2014, a 6-month period that included one dry season and one rainy season. Initiating captures at the given time, and not earlier, lowered the probability of catching bats that had not yet fed. Captured bats were placed inside cloth bags and transported to a working station for processing. Frugivorous individuals were identified to the species level, following Gardner's (2007d) key; measures of forearm and leg length, wing area (from right wing) and weight were taken; and the sex of each individual was recorded.

Finally, the bats were marked on their wings with a veterinary tattoo punch using consecutive numbers. Compared to other marking techniques, this method apparently does not compromise the health of the individuals (Kunz $\&$ Weise, 2009). By marking bats, philopatry to the study site could be determined.

Collection and analysis of bat feces samples: Feces were collected directly from the cloth bags where each individual had been independently deposited immediately after being captured in a mist net and from the ground under the net precisely underneath the place of capture. The ground had been covered with plastic sheet to facilitate the collection of samples. Feces samples were deposited in paper bags, tagged and dried in the shade for later identification. Afterwards, the samples 
were washed with distilled water, and their contents were identified with a Leica EZ4 stereoscopic microscope. Seeds found in the feces were identified to the lowest possible taxonomic level.

Plant collection and availability of $P$. tuberculatum: Samples from plants that are eaten by bats were collected (i.e., Cecropia, Solanum, Ficus and Piper) (Saldaña-Vázquez et al., 2013) and used as references for the identification of seeds obtained from bat feces at the Seed Laboratory at the Universidad del Valle. From August onward, two 4 x 50 m fixed plots were set in each study site for a total of eight plots. The availability of ripe $P$. tuberculatum fruits was evaluated monthly in each plot, with the total number of ripe fruits being estimated by counting fruits on a branch and counting the total number of branches per tree (Acosta-Rojas, Muñoz, Torres, \& Corredor, 2012). Immature fruits were defined as those light green to dark green colored infrutescences with hard texture. On the other hand, mature fruits were defined as those dark green colored infrutescences with soft texture and a strong fragrant smell.

Niche overlap: "Consumption events," defined as the presence of certain food resource found in a fecal sample of a particular bat species, were determined. If $P$. tuberculatum and Ficus sp. seeds were found in a sample, one consumption event was recorded for each plant species for that bat species. Based on consumption events, overlap indexes among species were estimated using the Pianka index (1974). This index yields values between 0 and 1: a value of zero means no overlap, and a value of 1 indicates total niche overlap.

To compare the proportion of $P$. tuberculatum consumed among bat species a Friedman test was performed. Also, a discriminant analysis was performed with data recorded for forearm length, leg length, weight and wing area for mid-sized bat species (groups) that consume $P$. tuberculatum, S. lilium and Carollia spp. to evaluate whether there were similarities in the morphology of bats that eat these fruits. Considering that variables were on different scales and had different measurement units, data were standardized to a mean of 0 and a standard deviation of 1 . In addition, analysis of variance was performed comparing the wing area and forearm length of these species, along with a post hoc Tukey test.

\section{RESULTS}

Bat captures and feces collection: A total of 1522 individuals of fruit-eating bats from 14 species (Table 1) were captured. Four of these species showed evidence of $P$. tuberculatum consumption: Sturnira lilium, Carollia brevicauda, C. perspicillata and Artibeus lituratus. Regardless of species, recaptures occurred in low numbers compared to the number of marked individuals (Table 1), indicating that there is no philopatry in the population of Carollia with respect to $P$. tuberculatum availability in the area. Fecal samples were obtained from $19.5 \%$ of the captured individuals. For those plants with large seeds, consumption events were recorded only when bats were captured in the net with the fruits. However, the characteristic odor and color of ripe mango pulp allowed their identification from the fresh feces samples, without the presence of seeds being required.

Artibeus lituratus was the most abundant species in the study period. However, the four species that consumed $P$. tuberculatum followed a similar pattern of variation in abundance during the sampling period. In the first two months, June and July, the highest number of bats was captured, with A. lituratus and $S$. lilium being the most frequent in July (Fig. 1). From August onward, the capture rate of those four species decreased.

For S. lilium, P. tuberculatum was the main food component, with the highest number of consumption events (above $60 \%$ ), followed by Solanum nudum and Piper aduncum in smaller proportions (Fig. 2). C. brevicauda and C. perspicillata showed preferences for plants from the genus Piper; Piper tuberculatum, 
TABLE 1

Species of frugivorous bats captured and fecal samples obtained in Robles, Valle del Cauca, Colombia

\begin{tabular}{|c|c|c|c|c|}
\hline Species & $\begin{array}{l}\text { No. of marked } \\
\text { individuals }\end{array}$ & No. of recaptures & $\begin{array}{c}\% \text { of samples } \\
\text { obtained (n) }\end{array}$ & $\mathrm{NI}^{1}$ \\
\hline Anoura sp. & 1 & & & \\
\hline Artibeus lituratus (Olfers, 1818) & 1122 & 14 & $11.4(130)$ & 2 \\
\hline Artibeus jamaicensis Leach, 1821 & 29 & & & \\
\hline Carollia brevicauda (Schinz, 1821) & 38 & 2 & $67.5(27)$ & 3 \\
\hline Carollia castanea Allen, 1890 & 2 & & & \\
\hline Carollia perspicillata (Linnaeus, 1758) & 70 & 6 & $63.2(48)$ & 2 \\
\hline Enchisthenes hartii (Thomas, 1892) & 3 & & & \\
\hline Glossophaga soricina (Pallas, 1766) & 137 & & & \\
\hline Platyrrhinus helleri (Peters, 1866) & 13 & & & \\
\hline Phyllostomus discolor Wagner, 1843 & 31 & & & \\
\hline Phyllostomus hastatus (Pallas, 1767) & 3 & & & \\
\hline Sturnira lilium (É. Geoffroy, 1810) & 69 & 7 & $70.7(53)$ & 2 \\
\hline Uroderma bilobatum Peters, 1866 & 3 & & & \\
\hline Vampyressa thyone Thomas, 1909 & 1 & & & \\
\hline Total & 1522 & & & \\
\hline
\end{tabular}

1. $\mathbf{N I}=$ Maximum number of different items found in a fecal sample.

other Piper spp. and arthropods were the main food items recorded. In the case of $A$. lituratus, only two $P$. tuberculatum consumption events were recorded; this species' diet was mainly composed by fruits of Ficus spp., Psidium guajava and Mangifera indica. The species A. lituratus and C. perspicillata had the most diverse consumption events, with the highest number of distinct items recorded. According to the species accumulation curve and the species richness estimators (ACE and CHAO1), a representativeness of more than $85 \%(91 \%$ and $86 \%$, respectively) of the plants consumed by bats was obtained (Fig. 3). Furthermore, the Friedman test showed statistically significant differences among the proportion of $P$. tuberculatum consumed by the four bat species $\left(X^{2}\right.$ $=12.26$, d.f. $=3, P=0.0065$ )

P. tuberculatum availability: A total of 15 individuals of $P$. tuberculatum were recorded in the eight plots surveyed. During the six months of the study, $P$. tuberculatum trees had infructescences with immature fruits and mature fruits (in a lesser proportion) (Table 2).
In addition, three shrubs of Solanum nudum were recorded outside the plots, and the fruits of these shrubs were consumed by S. lilium and C. perspicillata.

Niche overlap: The greatest niche overlap was recorded between $C$. brevicauda and C. perspicillata, followed by $S$. lilium and $C$. perspicillata (Table 3). C. perspicillata shared five out of the six food resources recorded for S. lilium. Moreover, C. perspicillata consumed arthropods and three additional species of plants, two of which belong to the genus Piper. However, C. perspicillata shared five out of the six food resources consumed by $C$. brevicauda, with one food being an arthropod and the remaining being fruit from Piper spp. In contrast, the lowest niche overlap was observed between A. lituratus and each of the three frugivorous bat species that were captured.

The discriminant analysis showed that there is morphological differentiation between the Carollia and the Sturnira groups (Fig. 4A). For the first discriminant function, wing area is the most important characteristic for use in 


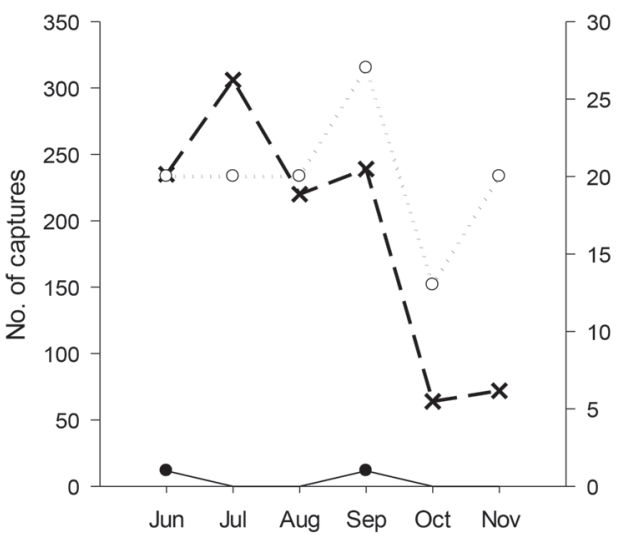

Sturnira lilium

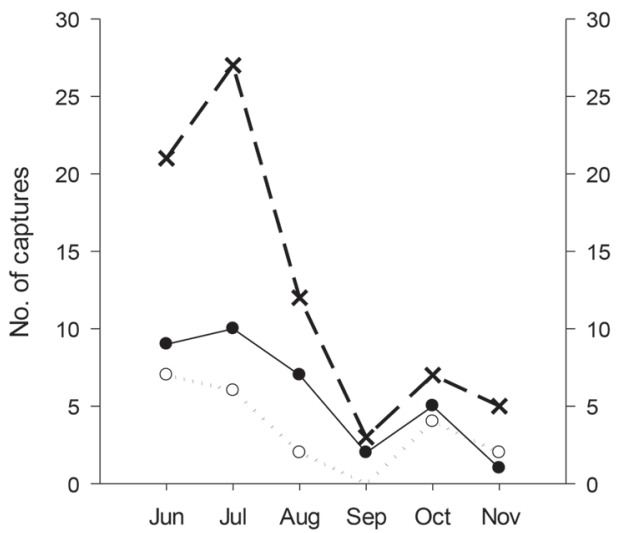

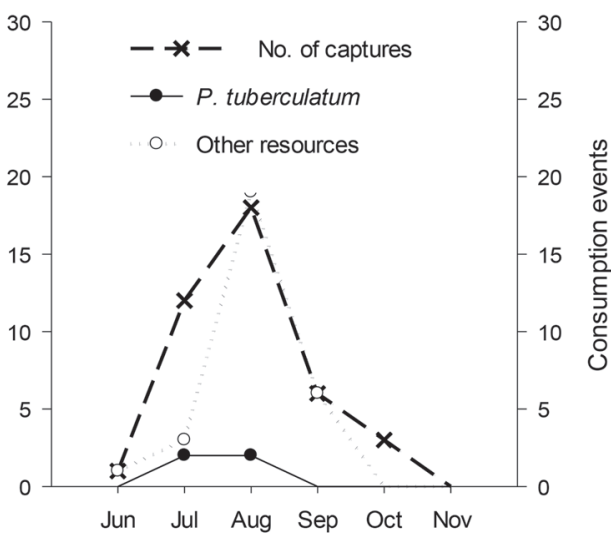

Carollia perspicillata

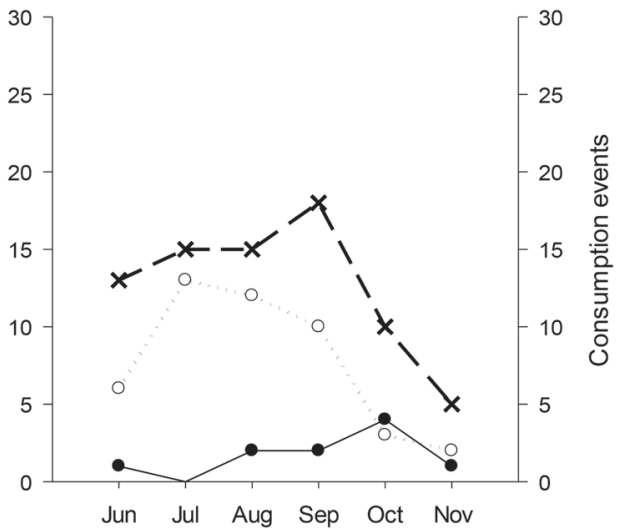

Fig. 1. Consumption events and number of captures of frugivorous bats that consumed Piper tuberculatum in Robles, Valle del Cauca, Colombia.

distinguishing between the two groups, followed by forearm length. The second discriminant function did not separate the individuals into groups. Sturnira lilium was smaller than C. brevicauda and C. perspicillata (Table 4).

In the analysis of variance, C. brevicauda and $C$. perspicillata did not show significant differences in either wing area $(\mathrm{P}=0.41)$ or in forearm length $(\mathrm{P}=0.9)$, whereas $\mathrm{S}$. lilium showed significant differences with both Carollia species ( $\mathrm{P}<0.01$ in both cases). Sturnira lilium had a smaller wing area and forearm length than the Carollia spp. (Fig. 4B).

\section{DISCUSSION}

In Robles, $S$. lilium was the main consumer of $P$. tuberculatum, establishing a SturniraPiper interaction. These results differ from those found in similar studies, where P. tuberculatum is the plant most frequently consumed by $C$. perspicillata, whereas $S$. lilium has been reported to consume mainly Solanum nudum (Heithaus et al., 1975).

According to these results, the interactions Carollia-Piper and Sturnira-Solanum should not be generalized, as they could vary between 

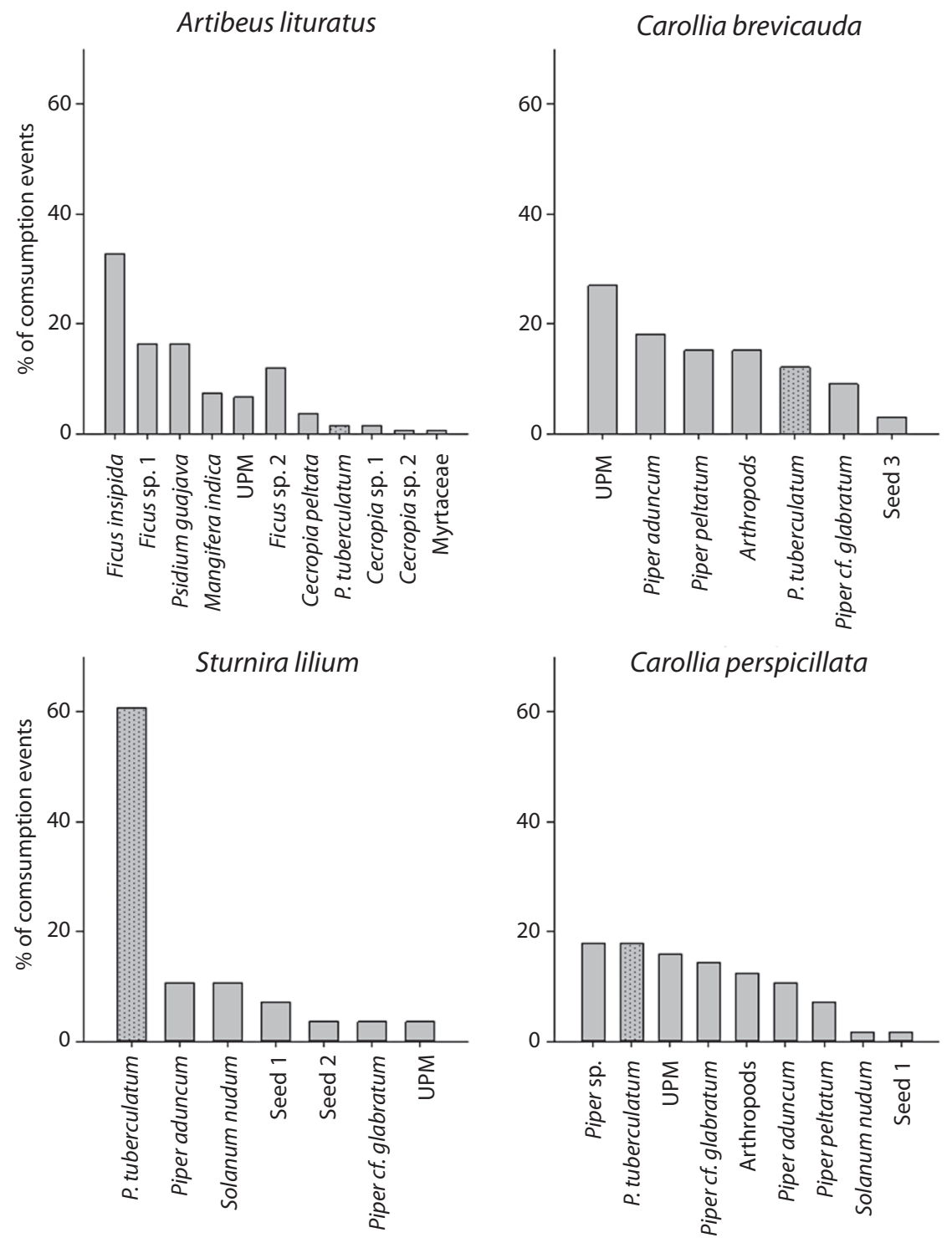

Food resource

Food resource

Fig. 2. Proportion of consumption events of food resources for species of frugivorous bats in Robles, Valle del Cauca, Colombia. Abbreviation: UPM $=$ Unidentified plant material.

specific geographic places. Saldaña-Vázquez et al. (2013) postulated that the latitude where Sturnira is located might affect Solanum consumption, with decreasing consumption of Solanaceae observed closer to the Equator due to the high diversity of plants edible by bats in those areas. However, in their review, the authors agree that Piper species are ranked second among the preferred food items by this genus of bats.

Sturnira lilium seems selective when feeding. Mello et al. (2008) reported that although their study area contained other available fruits, Piper spp. among them, Solanaceae fruits were the main food of this bat species, indicating an active selection of fruits and a nonopportunistic 


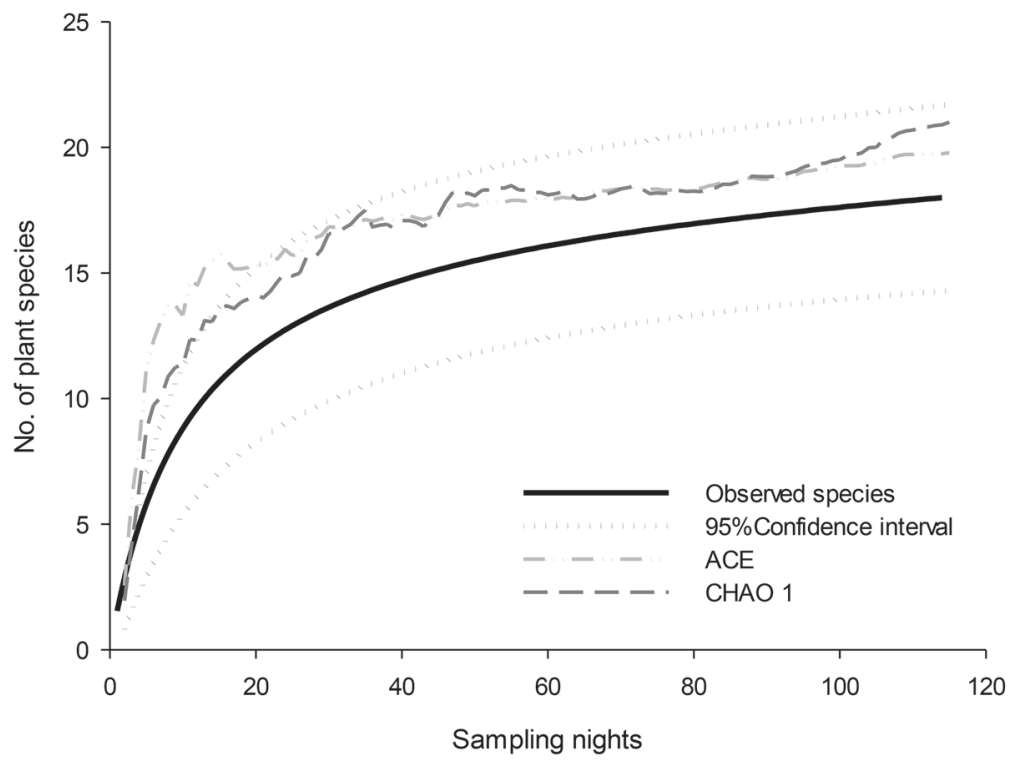

Fig. 3. Species accumulation curve for plant species consumed by frugivorous bats in Robles, Valle del Cauca, Colombia.

TABLE 2

Number of fruits of Piper tuberculatum in eight fixed plots in Robles, Valle del Cauca, Colombia

\begin{tabular}{lcccccccc} 
& \multicolumn{2}{c}{ August } & \multicolumn{2}{c}{ September } & \multicolumn{2}{c}{ October } & \multicolumn{2}{c}{ November } \\
& IMF $^{1}$ & MF $^{2}$ & IMF & MF & IMF & MF & IMF & MF \\
Plant 1 & 575 & 0 & 485 & 10 & 0 & 130 & 96 & 0 \\
Plant 2 & 0 & 0 & 20 & 0 & 144 & 0 & 10 & 0 \\
Plant 3 & 38 & 20 & 0 & 0 & 90 & 0 & 0 & 3 \\
Plant 4 & 40 & 1 & 15 & 0 & 0 & 0 & 0 & 1 \\
Plant 5 & 27 & 18 & 25 & 0 & 0 & 0 & 0 & 1 \\
Plant 6 & 30 & 12 & 24 & 0 & 0 & 0 & 0 & 0 \\
Plant 7 & 240 & 146 & 28 & 0 & 112 & 200 & 150 & 0 \\
Plant 8 & 243 & 140 & 84 & 0 & 130 & 160 & 170 & 0 \\
Plant 9 & 239 & 130 & 112 & 0 & 128 & 100 & 100 & 0 \\
Plant 10 & 40 & 0 & 147 & 0 & 20 & 0 & 76 & 4 \\
Plant 11 & 48 & 0 & 0 & 0 & 264 & 11 & 248 & 8 \\
Plant 12 & 14 & 0 & 7 & 0 & 12 & 0 & 20 & 0 \\
Plant 13 & 24 & 0 & 11 & 0 & 21 & 2 & 248 & 8 \\
Plant 14 & 192 & 0 & 25 & 0 & 120 & 0 & 29 & 1 \\
Plant 15 & 35 & 0 & 13 & 0 & 0 & 0 & 80 & 0 \\
\hline
\end{tabular}

1. $\mathrm{IMF}=$ Immature fruits.

2. $\mathrm{MF}=$ Mature fruits.

response to fruit abundance. Therefore, consumption of fruits of other plant families may serve as an energy or mineral supplement (Fleming, 1986; Mello et al., 2008). However, in Robles, the reason $S$. lilium selects fruits of $P$. tuberculatum over other food resources seems to be related to the low availability of Solanum spp. fruits in contrast to P. tuberculatum availability. Therefore, as Saldaña-Vázquez et al. (2013) suggest, the Sturnira-Solanum 
TABLE 3

Food resource niche overlap calculated with Pianka's (1974) index for frugivorous bats in Robles, Valle del Cauca, Colombia

\begin{tabular}{lccc} 
& Artibeus lituratus & Carollia brevicauda & Carollia perspicillata \\
Artibeus lituratus & 1 & & \\
Carollia brevicauda & 0.013 & 1 & 1 \\
Carollia perspicillata & 0.018 & 0.765 & 0.593 \\
Sturnira lilium & 0.033 & 0.475 & \\
\hline
\end{tabular}
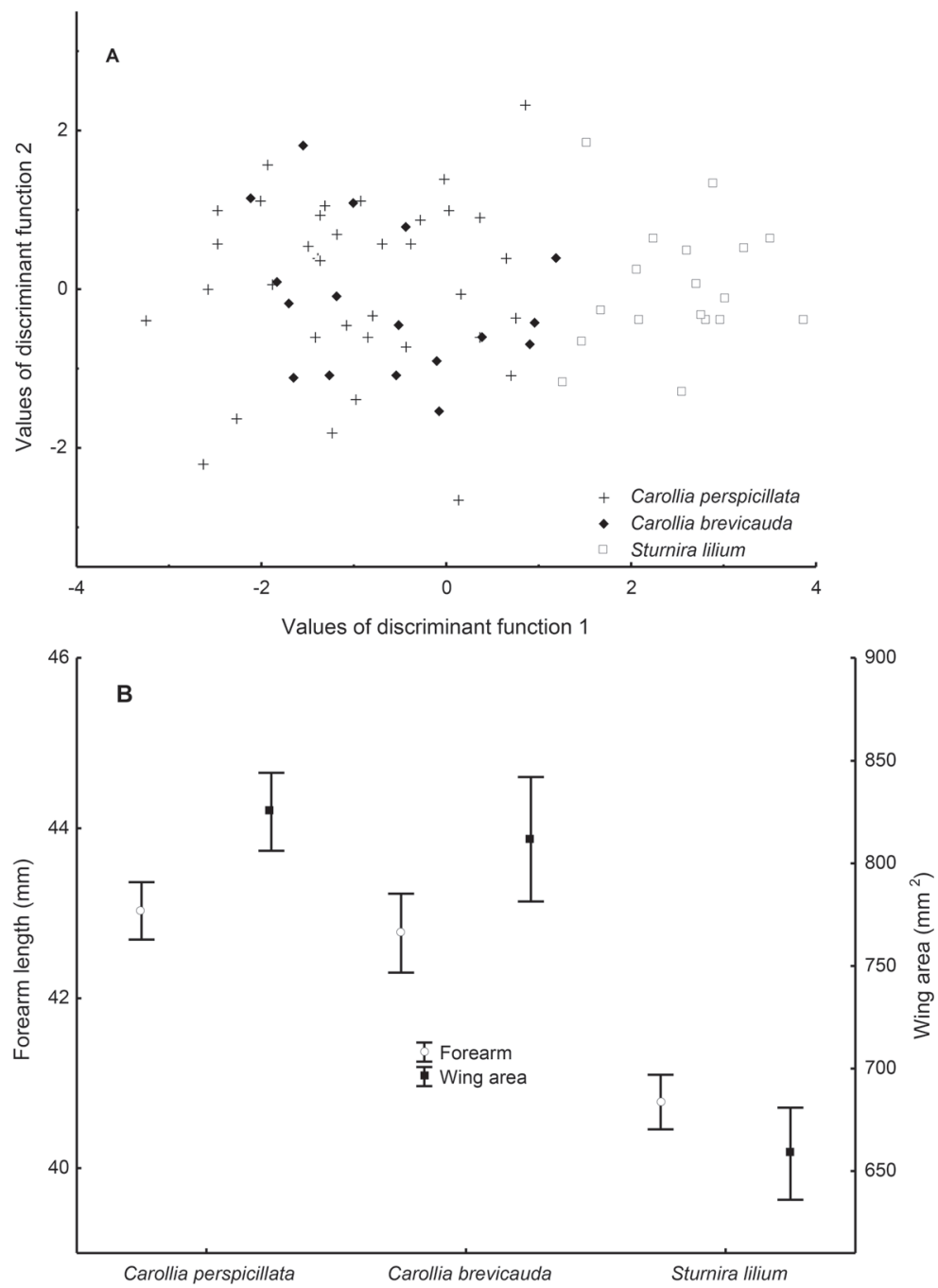

Fig. 4. Morphological comparison between Carollia brevicauda, C. perspicillata and Sturnira lilium in Robles, Valle del Cauca, Colombia: A) Discriminant analysis, B) Comparison of forearm length and wing area. 
TABLE 4

Mean ( \pm standard deviation) of morphological traits measured and their standardized coefficients of the two discriminant functions resulting from a discriminant analysis of individuals of the bat species Carollia brevicauda, Carollia perspicillata and Sturnira lilium in Robles, Valle del Cauca, Colombia

\begin{tabular}{lccccc} 
& C. brevicauda & C. perspicillata & S. lilium & DFC1 $^{1}$ & DFC2 $^{2}$ \\
$\mathrm{n}$ & 17 & 36 & 18 & & \\
Forearm $(\mathrm{mm})$ & $42.8( \pm 0.9)$ & $43( \pm 1)$ & $40.8( \pm 0.6)$ & -0.43 & 0.31 \\
Leg $(\mathrm{mm})$ & $11.8( \pm 0.9)$ & $12.1( \pm 1)$ & $10.5( \pm 1)$ & -0.3 & 0.41 \\
Weight $(\mathrm{g})$ & $20.1( \pm 2.4)$ & $19.8( \pm 2.8)$ & $18.1( \pm 2.3)$ & -0.03 & -0.85 \\
Wing area $\left(\mathrm{mm}^{2}\right)$ & $811.8( \pm 58.9)$ & $825.2( \pm 56.2)$ & $658.5( \pm 45.2)$ & -0.6 & -0.27 \\
\hline
\end{tabular}

1. $\quad$ DFC1 $=$ Standardized coefficient of discriminant function 1 .

2. $\quad$ DFC2 $=$ Standardized coefficient of discriminant function 2 .

interaction is controlled by the presence of other high-quality fruits, such as Piper, which is indicated by the higher consumption of Piper in the present study.

Frequent consumption of $P$. tuberculatum by $S$. lilium is not necessarily directly related to the successful dispersal and recruitment of new individuals of $P$. tuberculatum. Fleming (1981) demonstrated that the average number of seeds produced by Piper amalago has an extremely reduced probability of surviving or becoming a reproductive adult because the bats that consume them kill (most likely indirectly) more seeds than they disperse to optimal places. Moreover, germination and sapling stages suffer high mortality. All these traits may characterize the interaction between $P$. tuberculatum and its dispersers, a hypothesis to be tested in situ.

The dispersal distance of seeds from the parent plant is affected by the foraging patterns of bats. Sturnira lilium flies relatively short distances, which may restrict maximum distances of seed dispersal (Heithaus et al., 1975). The presence of $C$. perspicillata roosting sites in $\mathrm{La}$ Selva, Costa Rica, significantly increases richness, abundance and local diversity of Piper spp. compared to other places without nearby shelters. Seed dispersal is therefore directed and nonrandom (Salazar, Kelm, \& Marquis, 2013). As a result, habitats devoid of resources, or actively avoided by dispersers (e.g., due to the incidence of predators), will receive a lower seed rain, which will lead to decreased diversity (Estrada-Villegas, Pérez-Torres, \& Stevenson, 2007).

The higher niche overlap was shown by congeners $C$. brevicauda and C. perspicillata followed by C. perspicillata and S. lilium. Likewise the discriminant analysis grouped both Carollia species, and statistical analyses did not show significant differences in their morphology. However, statistical analysis did show differences in morphology between Carollia spp. and S. lilium which uses similar food resources. Thus, this difference in body size may be associated with their dietary patterns and may be responsible for the consumption of food items other than $P$. tuberculatum by Carollia spp. considering that this hypothesis has been already tested in bats of the genus Carollia: For coexisting species of different body sizes, the proportion of Piper fruits consumed will vary; the larger species will consume the lowest quantity of Piper fruits because it has access to larger fruits (Fleming, 1991). Accordingly similar morphology in $C$. brevicauda and C. perspicillata in Robles indicates that both species have access to the same dietary resources.

In contrast, the lowest niche overlap was shown by $A$. lituratus with the remaining species. This is due, in part, to the large size of $A$. lituratus compared to C. brevicauda, C. perspicillata and S. lilium (Gardner, 2007c; MarquesAguiar, 2007; McLellan \& Koopman, 2007). 
The maximum size of a fruit that is transportable by a bat is directly related to the size of the bat (Fleming, 1986), thus Artibeus lituratus has access to larger fruits (e.g., Ficus spp., Psidium guajava and Mangifera indica).

In conclusion, $S$. lilium is the most important consumer of $P$. tuberculatum in Robles, but this bat species cannot be identified as an effective disperser. For bats of the genus Carollia present in the area, P. tuberculatum does not represent the main food source, as indicated by consumption of other resources in equal or greater amounts, however the high niche overlap shown by this two species may suggest a potential competition. Consumption of Piper by Sturnira seems to indicate the low availability of Solanum. Artibeus lituratus is a generalist species, and is an occasional consumer of $P$. tuberculatum, furthermore, its large body size allows this bat species to have access to a broad quantity of food sources. This study leaves unanswered questions about the germination and recruitment potential of the seeds and the bromatological aspects of $P$. tuberculatum; therefore, there is a need to replicate these types of studies over other ecosystems to confirm the dynamics of the Sturnira-Solanum and Sturnira-Piper interactions in other neotropical forests.

\section{ACKNOWLEDGMENTS}

The authors thank Natalya Zapata-Mesa, Johanna López-Ortega and Ana M. SoriaEscobar for their assistance in field and laboratory work. They also thank Carlos González, director of FUNECOROBLES, and his family for the support with the community of Robles. Thanks go to farm owners Bernardo Viveros, Eduardo Mina, José Mina, Clara González, Manuel González and Jaime Posada. Thanks to Martha Espinosa for allowing access to their facilities; to Oscar Murillo-García for his advice on the identification of Carollia species; and to Antonio Santos-Moreno and Cristian Craker-Castañeda for their valuable comments on the manuscript. Lastly, we acknowledge the logistical support of the Universidad del Valle and the Wildlife Conservation Society Colombia program.

\section{RESUMEN}

Interacciones entre murciélagos frugívoros (Chiroptera: Phyllostomidae) y Piper tuberculatum (Piperaceae) en un bosque seco tropical en Valle del Cauca, Colombia. La coexistencia de las especies de un gremio trófico depende de la división y el uso de recursos. Los frutos en cualquier ecosistema son recursos alimenticios que varían en el tiempo y el espacio, así como en su contenido nutricional, por ende, los organismos que dependen de éstos como fuente alimenticia, tienden a presentar cierto grado de especialización. La comprensión de los factores que influyen en la dinámica de la dispersión de semillas es importante para la regeneración y conservación de los ecosistemas tropicales. Nuestro objetivo fue determinar cómo varía el consumo de Piper tuberculatum (Pipilongo) por parte del ensamblaje de murciélagos frugívoros en el corregimiento de Robles (Jamundí, Valle del Cauca, Colombia). P. tuberculatum es un recurso utilizado no solo por la fauna, sino también por los habitantes del corregimiento de Robles. Se capturaron murciélagos en redes de niebla entre junio y noviembre 2014, sus heces fueron recolectadas y medidas de la longitud del antebrazo, área alar, longitud de la pata y el peso fueron registradas. En el laboratorio de semillas de la Universidad del Valle, se lavaron las muestras y se determinó su contenido. Las especies Sturnira lilium, Carollia brevicauda, C. perspicillata, y Artibeus lituratus mostraron evidencia de consumo de frutos de P. tuberculatum, entre las 14 especies de murciélagos frugívoros capturadas. Entre ellas, S. lilium fue la principal consumidora de $P$. tuberculatum, con el mayor número de eventos de consumo de esta especie, mientras que las otras especies de murciélagos tuvieron eventos de consumo más diversos. El mayor traslape de nicho se registró entre las especies $C$. brevicauda y C. perspicillata, los cuales presentaron un tamaño similar (i.e., área alar, antebrazo), seguido de $S$. lilium y $C$. perspicillata. En contraste, el menor traslape de nicho se registró para A. lituratus con cada una de las otras tres especies de murciélagos frugívoras registradas. En conclusión, Sturnira lilium mostró una relación Sturnira-Piper, la cual es el resultado de la baja disponibilidad de Solanum, siendo ésta especie de murciélago el mayor consumidor de $P$. tuberculatum de la región.

Palabras clave: dieta, dispersión de semillas, murciélagos frugívoros, pipilongo Sturnira, Carollia.

\section{REFERENCES}

Acosta-Rojas, D. C., Muñoz, M., Torres, A. M., \& Corredor, G. (2012). Dieta y dispersión de semillas: ¿Afecta la guacharaca colombiana Ortalis columbiana) la 
germinación de las semillas consumidas? Ornitología Neotropical, 23, 439-453.

Bonaccorso, F. J., Winkelmann, J. R., Shin, D., Agrawal, C. I., Aslami, N., Bonney, C., Hsu, A., Jekielek, P. E., Knox, A. K., Kopach, S. J., Jennings, T. D., Lasky, J. R., Menesale, S. A., Richards, J. H., Rutland, J. A., Sessa, A. K., Zhaurova, L., \& Kunz, T. H. (2006). Evidence for exploitative competition: comparative foraging behavior and roosting ecology of shorttailed fruit bats (Phyllostomidae). Biotropica, 39(2), 249-256.

Chacón, P., Osorio-García, A. M., Achury, R., \& Bermúdez, C. (2012). Hormigas (Hymenoptera: Formicidae) del Bosque seco Tropical (Bs-T) de la cuenca alta del río Cauca, Colombia. Biota Colombiana, 13(2), 165-181.

Charles-Dominique, P. (1993). Speciation and Coevolution: An interpretation of frugivory phenomena. Vegetatio, 107/108, 75-84.

Dumont, E. R. (1999). The effect of food hardness on feeding behaviour in frugivorous bats (Phyllostomidae): an experimental study. Journal of Zoology, 248, 219-229.

Dumont, E. R. (2003). Bats and fruit: An ecomorphological approach. In T. H. Kunz \& M. B. Fenton (Eds.), Bat Ecology (pp. 398-429). Chicago, USA: University of Chicago Press.

Estrada-Villegas, S., Pérez-Torres, J., \& Stevenson, P. (2007). Dispersión de semillas por murciélagos en un borde de bosque montano. Ecotropicos, 20(1), 1-14.

Feldhamer, G. A., Drickamer, L. C., \& Vessey, S. H. (2003), Mammalogy: Adaptation, Diversity, and Ecology (2nd ed.). Singapore: McGraw Hill.

Fleming, T. H. (1979). Do tropical frugivores compete for food? American Zoologist, 19(4), 1157-1172.

Fleming, T. H. (1981). Fecundity, fruiting pattern, and seed dispersal in Piper amalago (Piperaceae), a batdispersed tropical shrub. Oecologia, 51(1), 42-46.

Fleming, T. H. (1985). Coexistence of five sympatric Piper (Piperaceae) species in a tropical dry forest. Ecology, 66(3), 688-700.

Fleming, T. H. (1986). Opportunism versus specialization: the evolution of feeding strategies in frugivorous bats. In A. Estrada, \& T. H. Fleming (Eds.), Frugivores and Seed Dispersal (pp. 105-118). Dorddrecht: Dr. W. Junk Publish.

Fleming, T. H. (1991). The relationship between body size, diet, and habitat use in frugivorous bats, genus Carollia (Phyllostomidae). Journal of Mammalogy, 72(3), 493-501.
Fleming, T. H., \& Kress, W. J. (2011). A brief history of fruits and frugivores. Acta Oecologica, 37, 521-530.

Fleming, T. H., Heithaus, E. R., \& Sawyer, E. B. (1977). An experimental analysis of the food location behavior of frugivorous bats. Ecology, 58(3), 619-627.

Gardner, A. L. (2007a). Family Phyllostomidae Gray, 1825. In A. L. Gardner (Ed.), Mammals of South America: marsupials, xenarthrans, shrews and bats (pp. 207). Chicago, USA: University of Chicago Press.

Gardner, A. L. (2007b). Subfamily Stenodermatinae P. Gervais, 1856. In A. L. Gardner (Ed.), Mammals of South America: marsupials, xenarthrans, shrews and bats (pp. 300). Chicago, USA: University of Chicago Press.

Gardner, A. L. (2007c). Tribe Sturnirini. In A. L. Gardner (Ed.), Mammals of South America: marsupials, xenarthrans, shrews and bats (pp. 363-376). Chicago, USA: University of Chicago Press.

Gardner, A. L. (2007d). Mammals of South America: marsupials, xenarthrans, shrews and bats. Chicago, USA: University of Chicago Press.

Heithaus, E. R., Fleming, T. H., \& Opler, P. A. (1975). Foraging patterns and resource utilization in seven species of bats in a seasonal tropical forest. Ecology, $56(4), 841-854$.

Hill, J. E., \& Smith, J. D. (1984). Bats: a natural history. Austin, Texas: University of Texas Press.

Holdridge, L. R. (1967). Life zone ecology (2 $2^{\text {nd }}$ ed.). San José, Costa Rica: Tropical Science Center.

Kunz, T. H., \& Weise, C. D. (2009). Methods and devices for marking bats. In T. H. Kunz \& S. Parsons (Eds.), Ecological and Behavioral Methods for the Study of Bats ( $2^{\text {nd }}$ ed., pp. 36-56). Baltimore, Maryland, USA: John Hopkins University Press.

López, J. E., \& Vaughan, C. (2007). Food niche overlap among neotropical frugivorous bats in Costa Rica. Revista de Biología Tropical, 55(1), 301-313.

Marinho-Filho, J. S. (1991). The coexistence of two frugivorous bat species and the phenology of their food plants in Brazil. Journal of Tropical Ecology, 7(1), 59-67.

Marques-Aguiar, S. A. (2007). Genus Artibeus Leach, 1821. In A. L. Gardner (Ed.), Mammals of South America: marsupials, xenarthrans, shrews and bats (pp. 301-321). Chicago, USA: University of Chicago Press.

McLellan, L. J., \& Koopman, K. F. (2007). Subfamily Carolliinae Miller, 1924. In A. L. Gardner (Ed.), Mammals of South America: marsupials, xenarthrans, shrews and bats (pp. 208-217). Chicago, USA: University of Chicago Press. 
Mello, M. A. R., Kalko, E. K. V., \& Silva, W. R. (2008). Diet and abundance of the bat Sturnira lilium (Chiroptera) in a brazilian montane atlantic forest. Journal of Mammalogy, 89(2), 485-492.

Mello, M. A. R., Schittini, G. M., Selig, P., \& Bergallo, H. G. (2004). A test of the effects of climate and fruiting of Piper species (Piperaceae) on reproductive patterns of the bat Carollia perspicillata (Phyllostomidae). Acta Chiropterologica, 6(2), 309-318.

Muscarella, R., \& Fleming, T. H. (2007). The role of frugivorous bats in tropical forest succession. Biological Reviews, 82, 573-590.

Parmar, V. S., Jain, S. C., Bisht, K. S., Jain, R., Taneja, P., Jha, A., Tyagi, O. D., Prasad, A. K., Wengel, J., Olsen, C. E., \& Boll, P. M. (1997). Phytochemistry of the genus Piper. Phytochemistry, 46(4), 597-673.

Pianka, E. R. (1974). Niche overlap and diffuse competition. Proceedings of the National Academy of Sciences, 71(5), 2141-2145.

Quijano-Abril, M. A., Callejas-Posada, R., \& MirandaEsquivel, D. R. (2006). Areas of endemism and distribution patterns for Neotropical Piper species (Piperaceae). Journal of Biogeography, 33, 1266-1278.

Salazar, D., Kelm, D. H., \& Marquis, R. J. (2013). Directed seed dispersal of Piper by Carollia perspicillata and its effect on understory plant diversity and folivory. Ecology, 94(11), 2444-2453.

Saldaña-Vázquez, R. A., Sosa, V. J., Iñiguez-Dávalos, L. I., \& Schondube, J. E. (2013). The role of extrinsic and intrinsic factors in Neotropical fruit bat-plant interactions. Journal of Mammalogy, 94(3), 632-639.

Smith, J. D. (1976). Chiropteran evolution. In R. J. Baker, J. K. Jones, Jr., \& D. C. Carter (Eds.), Biology of bats of the New World family Phyllostomatidae. Part I (pp. 49-70). Texas, USA: Texas Tech University Press.

Thies, W., \& Kalko, E. K. V. (2004). Phenology of neotropical pepper plants (Piperaceae), and their association with their main dispersers, two short-tailed fruit bats, Carollia perpicillata and C. castanea (Phyllostomidae). Oikos, 104(2), 362-376.

Thies, W., Kalko, E. K. V., \& Schnitzler, H. (1998). The roles of echolocation and olfaction in two Neotropical fruit-eating bats, Carollia perspicillata and $C$. castanea, feeding on Piper. Behavioral Ecology and Sociobiology, 42(6), 397-409.

Voigt, C. C., Kelm, D. H., Bradley, B. J., \& Ortmann, S. (2009). Dietary analysis of plant-visiting bats. In T. H. Kunz, \& S. Parsons (Eds.), Ecological and Behavioral Methods for the Study of Bat $\left(2^{\text {nd }}\right.$, pp. 593-609). Baltimore, Maryland, USA: John Hopkins University Press. 
